\title{
COOPETITION AND SMALL FIRMS VALUE CREATION
}

Adedeji Saidi Adelekan ${ }^{1}$, James Olanipekun Ojo ${ }^{2}$, Powel Maxwell Worimegbe ${ }^{3}$

${ }^{1}$ Dominican University, Ibadan, Nigeria

${ }^{2}$ Mountain Top University, Ibafo, Nigeria

${ }^{3}$ Olabisi Onabanjo University, Ago-Iwoye, Nigeria

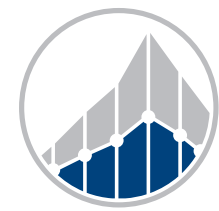

EUROPEAN JOURNAL OF BUSINESS SCIENCE AND TECHNOLOGY

Volume 7 Issue 2

ISSN 2694-7161

www.ejobsat.com

\begin{abstract}
Small firms are faced with the challenges of competing with larger firms. This has given birth to utilising different strategies to enhance the small firms' capacity to achieve their corporate goals. This study examines the nature of coopetition among small firms and how it has influenced their ability to create value. Employing the survey research design, the study sampled 1119 small firms and established the interaction between coopetition and value creation in small firms using the partial least square-structural equation model. The results reveal entrepreneurial orientation is the most prevalent type of coopetition among small firms and that coopetition is a significant driver of value creation among small firms. The study recommends that small firms should integrate coopetition into their strategy to remain relevant, increase their revenue, customise their services through value-added services and create new products and services.
\end{abstract}

\section{KEY WORDS}

coopetition, collaboration, competition, value creation, small business

\section{JEL CODES}

C30, D21, M13

\section{INTRODUCTION}

The firm environment's evolving nature has brought about new opportunities, alliances, challenges, and new ways of addressing variations in a firm's operations and performance. In most recent times, competing firms have come together to achieve their individual corporate goals by creating synergy and combin- ing strength and opportunities (Worimegbe, 2020). This paradoxical relation is known as coopetition (Arndt et al., 2018). Coopetition is a simultaneous situation where rival firms existing in the same market or with the same competencies combine resources to undertake a particular venture in other to achieve a 
win-win situation. Di Benedetto et al. (2019) assert that the primary purpose of collaboration among competing firms is to pursue goals that would be otherwise difficult to achieve alone. Coopetition is not the only alliance that could bring about achieving complex goals. However, coopetition reduces the complexities that could have been encountered in other forms of relationships since firms in coopetition have a better understanding of their core competencies and the needs of the market they operate (Seetharaman and Gallucci, 2020).

Crick and Crick (2020) opine that coopetition has changed firms' firm models by providing new ways of achieving their goals by sharing capabilities and resources while enjoying mutually beneficial outcomes. Coopetition as a firm strategy could exist regardless of the firms' strategic status (horizontal or vertical) and the number of years in operation. Using a judicious mixture of collaboration with manufacturers, consumers, and firms manufacturing complementary or similar goods, coopeting firms gain an advantage that is not feasible if they stand alone (Worimegbe, 2020). Hayes (2020) posits that competing small firms and emerging firms can collaborate to fight larger firms or integrate to capture the market that more prominent firms have already occupied. This relationship makes the smaller firms become more substantial entities, enhancing the individual firms' capacity to grow through cross-channel promotion. Coopetition can improve efficiency, create value, exploit and access scarce resources, drive innovation and achieve market traction and power among small firms (Bouncken et al., 2015; Ritala and Sainio, 2014).

Coopetition provides the best strategic option, creates the most efficient inter-firm relationship, and opens up opportunities for different firms' levels (Walley, 2007; Le Roy and Czakon, 2016). The role of small firms in the economy cannot be undervalued. Ackerman (1999) emphasises that small firms are indispensable in any society since they contribute immensely to the economy and that these contributions could be summarised into two. First, small firms are pivotal to the renewal processes that are apparent throughout market economies. That is, emerging firms and small firms are integral in the innovation and experimentation that brings about economic growth, technological change and productivity. Second, small firms are the most crucial mechanism utilised by many entrepreneurs to gain access to broader social and economic mainstreams as witnesses in the developed economies. Small firms are critical to the Nigerian economy as a whole.

Aladejebi (2020) believes that small firms are the major drivers of the Nigerian economy, providing employment, increasing gross domestic products, and leading to the country being the biggest economy in the economy. However, Turner and Akinremi (2020) explain that $80 \%$ of the small firms in Nigeria close shop within the first five years of their operations due to their inability to compete favourably with larger firms. Morris et al. (2007) reveal that applying a coopetition strategy in small firms operation will increase their capacity to play in the same terrain with larger firms and capture a substantial part of the market while increasing their competitiveness.

Various studies have established the impact of coopetition on customers experience in the banking sector (Worimegbe, 2020); the role of coopetition in innovation and market performance (Ritala and Tidström, 2014; Czakon, 2018); the influence of coopetition on tourism (Czakon et al., 2020); how coopetition has helped in the fight against global pandemic (Crick and Crick, 2020) and the underlying nature of coopetition among small firms (Morris et al., 2007) Yet, it has been observed some firms adopt coopetition more than others (Wang and Krakover, 2008) while the effect among the various firms varies greatly (Bouncken and Fredrich, 2016; Kylänen and Rusko, 2011). To the best of our knowledge, there is a dart of literature on how coopetition could drive small firms value creation in developing countries, especially in the Nigerian context. According to Czakon et al. (2020), there is a strong need for studies to investigate the influence of coopetition on firms' operations, while Crick and Crick (2020) suggests that it is critical to understand the nature of coopetition across 
all types and levels of industries. Therefore, this study seeks to establish the nature of coopetition among small firms in Nigeria and examine the extent to which coopetition could drive the survival of these firms. Small firms' choice as the theatre of the study was influenced by Turner and Akinremi (2020) assertions, who argue that most small firms do not survive due to large firms' coopetition. Thomason et al. (2013) point out that coopetition is better identifiable in small firms because they are more proactive, intentional and interactive in their coopetitive relationship than larger firms and that smaller firms will find coopetition relatively easier than larger firms. In achieving the main objective of the study, three specific questions where postulated in strengthening the literature on coopetition and small firms performance:

1. What is the nature of coopetition among small firms in Nigeria?

2. To what extent does coopetition affect small firms value creation?

3. Which of the dimensions of coopetition and value creation should the small firms pursue?

\section{LITERATURE REVIEW}

\subsection{Construct of Coopetition and Its Measurement}

Coopetition's paradoxical nature has been extensively discussed in the extant literature (Gnyawali and Charleton, 2018; Czakon and Czernek, 2016; Park et al., 2014). Bengtsson and Kock (2000) explains that coopetition is a simultaneous relationship where the degree of competition is matched with the magnitude of cooperation within a particular industry. As firms collaborate, they do not let go of their original nature but interact with other firms in the same industry with some level of rivalry. Cygler et al. (2018) note that coopetition increases a firm's capacity to be more innovative, efficient, understand why their rivals undertake specific actions in the industry and do not weaken a firm's ability to compete. Jankowska (2010) argues that although the coopetition relationship is seen as opposite behaviour, it is pivotal for sustaining a firm's survival and competitiveness. Competitive collaboration among firms is generally seen as a strategic option employed to provide the firm with the unique opportunity to access resources that would have been too onerous to utilise (Stadtler and Van Wassenhove, 2016). Coopetition strategy does not negate the individualistic drive and corporate goals; instead, it increases a firm's capacity to achieve its goals by collaborating with its rivals in the same industry.
Moore (1993) explains that firms can no longer grow in a vacuum; instead, there is a need to attract strategic resources and strength through a partnership with available sundries; this, coopetition provides. Ornstein and Sandahl (2015) opine that coopetition can be created in vertical and horizontal relationships in reality and that the emergence of the collaborative relationship among competing firms changes the traditional view of either cooperating or competing. Small firms are challenged by the need to harness resources in the external environment to overcome their incapacities. Technology, innovation and knowledge management have been established as the main drivers of coopetition among firms and that where these constructs exist, there is protection against risks, opportunism, knowledge hoarding that would have risen as a result of such a complicated relationship while simultaneously enhancing strategic agility and innovation among collaborating firms (Gardete, 2016; Ritala et al., 2016; Soppe et al., 2014; Bouncken and Kraus, 2013).

The issue of measurement of coopetition in extant literature has been a significant concern, and this is because coopetition is multifaceted (Windsor, 2013). Contextual and systematic review show that coopetition measurements are industry-specific (Bengtsson et al., 2016; Czakon and Rogalski, 2014). Czakon et al. (2020) established that coopetition measure- 
ments are intra-industry competition, the degree of change in the industry, the existence and power of regulatory bodies, and the industrial recycling phase. Worimegbe (2020) and Czakon (2018) argue that the dimensions of coopetition are common central procurement (CCP), common risks management (CRM), strategic alliance (SA), common network governance (CNG) and sales of a common product with individual brands (SMFs). Luo (2007) reveals that the right measures of coopetition in small firms are strategic alliance, technological linkage, market dynamics. Crick and Crick (2019) validate that the measures of coopetition in small firms should be. However, this study adopts the measures proposed by Bengtsson and Johansson (2014). The authors suggest that small and medium firms coopete to create and sustain opportunities; therefore, coopetition could be measured from the standpoint of alliance portfolio management capabilities (APMC), entrepreneurial opportunities and industries specifics such as market convergence, temporal relationships and technological convergence. These measures reflect what is currently obtainable among small firms in Nigeria and are also in tandem with the opinion of Zgarni (2019).

Alliance portfolio collects focal firms who operate simultaneous and direct relationships or networks, which could increase revenues and the firm's capacity to capture more markets. According to Hoffmann (2007), the more extensive the alliance portfolio with different partners in by a firm, the more its access to a diversity of resources and information. Saebi (2011) asserts that although most small firms are aware of this strategy's importance, only a few of these firms have mastered the capacity to achieve successful performance through alliance portfolio. On the other hand, entrepreneurship opportunities are situations where firms or entrepreneurs create more viable channels and develop better capacities to create more values and create more values and lead to better performance. Klein (2010) posits that entrepreneurial opportunity deals with discovering, assessing and utilising opportunities to bring new services and goods into the market through actions that were not previously in existence. The entrepreneurial opportunities are driven by creativities, innovation, team building, leadership and technical skills (Windsor, 2013). The industry-specific measure explains the collaboration among industry players and how new standards are created through the strategies prevalent in such industries at a particular time (Bengtsson and Johansson, 2014). Industry specifics also involves the degree of customisation of products and services in the industry.

\subsection{Small Firms in Value Creation}

The groupings and definitions of small firms are divergent. The small and medium firms development agency (SMEDAN, 2019) define small firms as firms with 10-49 employees with a total value between 10,000-100,000 dollars. Olaolu and Obaji (2020) opine that small firms are pivotal to job creation, economic development, poverty alleviation, and improving living standards, although they encounter numerous hurdles in their operations. Worimegbe (2020) explains that small firms are critical in redistributing wealth and restructuring the macroenvironment to achieve sustainable goals. According to Machado (2016), growth is a pivotal drive in small firms and that their survival depends on their capacity to participate in strategic alliances, create values and compete with other firms in the market.

Small firms' growth is hinged on their ability to create value, and most small firms do not survive because they lack the strategy that will increase the capacity to compete (Worimegbe, 2020; McKelvie and Wiklund, 2010). Davidow (2018) opines that the right measures of value creation are systematically absent in existing literature. This is borne on the premise that available measures are centred on financial measures. Small firms are not most times concerned about net present values; rather, they seek alternative ways to make their firm more sustainable and competitive in the long run. Thiel and Masters (2018) suggests that small firm must create value and that not all values are useful to the firm and society. If a small firm exists in a competitive equilibrium industry, its 
strategy and survival will not matter in the market since an undifferentiated rival is ready to take its place (Jorgenson, 2015). Morris et al. (2007) argue that in comparison to large and medium firms, small firms are more vulnerable to rely on the patronage of the customers, suffer from the limited market, fluctuating demand and the ever-evolving firm environment.

Jorgenson (2015) posits that before a firm becomes profitable, it should be first concerned about value creation. Georgescu-Roegen (1971) asserts that a firm has created an economic value if it achieves the conditions of irreversibility (creating an irreversible value), fitness (creating values that benefit human purpose) and entropy (there is an increase in such value created). In order words, small firms create value through an irreversible process, which provides the resource holder more significant benefits for society. Sharma and Carney (2012) believe that financial measures for value creation do not capture the true essence of small firms. Merchant and Sandino (2009) are of the view that financial measures of value creation ignore value changes and economic values, conservatively biased, transaction-oriented and focus on the past. Jorgenson (2015) establishes that value creation should be measured in terms of revenue and the competitive cost of providing a service. Merchant and Sandino (2009) also suggest that a combination of revenue, customer satisfaction, productivity, research and development expenses and market shares should be employed to measure value creation. Value creation stems from the systematic implementation of strategies that costs, sales capital invested and capacity utilisation.

In determining the measures of value creation in this study, the point of view of Lieberman and Balasubramanian (2007) would be considered. The researchers posit that value created can only be captured by the consumer or the producer (small firms). Jorgenson (2015) argues that small firms fail when they do not create value for both the producers and consumers. Hence, non-financial measures will be adopted in this study. The choice is also influenced by the fact that most SMEs in Nigeria do not have proper accounting records (Olaolu and
Obaji, 2020). The non-financial measures that reveal value creation in both consumer and producers in small firms are sales, new markets, new service or product added and value-added services (Markgraf, 2020).

\subsection{Empirical Evidence Linking Coopetition and Small Firms}

Bengtsson and Johansson (2014) examine the interaction between coopetition small and medium-sized firms (SMEs) in the telecoms industry to create entrepreneurial opportunities in Sweden. The study explores SMEs' managerial issues when they employ the coopetition strategy with larger firms and how such a relationship could be balanced to sustain vital opportunities. Utilising three exploratory case studies, the study established that SMEs could increase their capacity by managing their status and maintaining their competitiveness through coopetition. The study demonstrated the alliance portfolio, industries specifics and entrepreneurial opportunities as measures of coopetition in SMEs. Ornstein and Sandahl (2015) investigate the link between coopetition and firm model. The study looks into how technological innovations have brought about rapid telecommunication and information technology firm environments. The changes witnessed has made firms change the way they operate and do firm and operate. They opined that it is not feasible for firms to operate in isolation any longer and that firms should engage in strategic alliances such as coopetition with horizontal and vertical competitors. The study further reveals that coopetition is necessary to create and deliver values that will enhance customers satisfaction and capture the market. The study enriches existing literature by connecting coopetition to firm models since value capture and value creation is the crux of both concepts. Morris et al. (2007) explore coopetition as a driver of small firm strategy and Turkey performance. The study investigates the nature of coopetition in small firms and its relevance to small firms' operations utilising the dimensions of mutual benefits, trust and commitment as a coopetition measure. Using 
a survey research design and a sample of 647 small firms, the study reveals that coopetition is based on mutual benefits in small firms and that coopetition dimensions employed in the study are dependent on one another.

Crick and Crick (2020) studied coopetition as a strategic tool for fighting the COVID-19 pandemic by small firms, technological firms, pharmaceutical organisations, nongovernmental organisations and retailers. The study contributed to the extant literature by revealing the heterogeneity of different firms during the global crisis. The study recommends that firms should evaluate the reward and risks involved in the coopetition strategy before integrating it into their actions. The authors suggest that it is critical to ascertain the nature of coopetition among the different players in the economy and to investigate further which is the most significant form of coopetition firms should embark on.

Worimegbe (2020) looks into how coopetition leads to customers experience in the Nigerian banking industry utilising technology as a moderating factor. The dimensions of common network governance, sales of a common product, strategic alliance and common central procedures were employed as coopetition measures. Using a sample of 1537 deposit money banks customers and the partial least square-structural equation model (PLS-SEM) analytical tool, the study established that coopetition is a driver of customers experience. The study recommends that further studies should be conducted in more vibrant sectors of the economy.

Zgarni (2019) study the supremacy of coopetition compared to cooperation in its pure form using internal and external factors. Employing the survey research design, the study sampled 400 Tunisian industrial firms and established that the influence of the simultaneous adoption of strategic capabilities and competitive intensity is significant in firm performance. The study further shows that the most significant dimension of coopetition affecting customers strategies while competitive intensity is the most considerable construct affecting suppliers' cooperation.
Czakon et al. (2020) evaluate the behavioural dimensions of coopetition by developing a scale. The study looks into managers' perception of what they believe coopetition among 368 polish tourism firms to understand why such managers adopt the coopetition strategy. A systematic review of coopetition literature reveals that the two most valid constructs of coopetition are coopetition mindset and strategic rationale. The confirmatory factor analysis shows that the two latent variables reaffirm that coopetition is intentional since the strategic rationale drives it. Besides, the study reveals that firms pursue coopetition with the motive of achieving the capacity they could not attain while operating alone. The authors contributed to the methodology and measurement instruments in coopetition while also empirically showing the connection between behavioural and rational dimensions of coopetitive strategic behaviour in firms. Randolph et al. (2018) analysed the inter-firm network social capital and information technology among fifteen non-profit organisations in the United States of America. The descriptive survey research was utilised in the study. 1,250 respondents were sampled. The validity and reliability of the research instruments employed reveals that legitimacy, resilience, knowledge sharing, cohesion and shared goals are measures of coopetition which will promote coopetition and significantly affect convergence among firms. The study also gives credence to the role of technology as a facilitator of coopetition.

\subsection{Research Gap}

While the empirical literature reveals the extent to which coopetition affect both SMEs and multinational firms' performance, the studies mentioned above did not empirically show how coopetition affects small firms value creation. The choice of value creation was influenced by the assertions of Jorgenson (2015), who opines that before a firm could be moved to make a profit and remain relevant in the long run, it must consider value creation first. Such value creation can be achieved through the right strategy. Hence the following hypotheses were formulated: 
Hypothesis 1: The dimension of alliance portfolio management capabilities significantly affects value creation in small firms.

Hypothesis 2: The dimension of entrepreneurial opportunities significantly affects value creation in small firms.

Hypothesis 3: The dimension of industries specifics significantly affects value creation in small firms.

\subsection{Theoretical Framework: Games Theory}

The study is anchored on the game theory. The game theory describes a situation of strategic interaction which involve two or more players (decision-makers) who can act in two or more ways (strategies) in such a way that the outcome of their actions is a function of the strategies the players employed (Bhuiyan, 2016). Each player has well-defined priorities of all the possible results, allowing corresponding utilities (payoffs) to be allocated. The rules governing players' interactions, the feasible tactics of players, and their expectations over results are evident in a game (Bicchieri and Sillari, 2005). The game theory is premised on the idea that a game has three pivotal elements; strategies, payoffs and players. In applying this to coopetition and value creation, the game theory explicitly explains the players as the competing small firms, strategies as coopetition and payoffs as the value created. Geckil and Anderson (2010) opine that a game can be distinguished from players' perspectives, according to rationality, cooperation, normal and extensive forms, and zero-sum and non-zerosum games. For evaluating various strategies in the firm world, game theory has become pivotal. It provides useful methods for solving problems with the process. Many firm strategies are plans for achieving sustainable profitability, either in the short or long term. A firm will often position itself effectively in the market with the right strategy, and a firm will suffer from the wrong plan in the long run. We believe coopetition and value creation are centred on the rationality and cooperation elements of the games' theory. This is because the rational player is one who, considering what he wants his rivals to do, always chooses an action that gives the result he likes most. Two severe manners can be distinguished. The first is referred to as the 'intelligent' player who behaves rationally. The other side is the player choosing for random acts (Bicchieri, 2007). Games may be classed as cooperative and non-cooperative. A game that requires players to collaborate on a joint strategy is called a 'cooperative game' (Bhuiyan, 2016). The assumption is that players (competing firms) would make strategic choices (coopetition) that will add value to their operations. Samuelson and Nordhaus (2010) argue that economic life entails numerous circumstances in which firms or other organisations engage strategically. Game theory analyses how two or more groups compete in an environment like a market and choose strategies or actions that affect all participants jointly. Hence, in the apriori, it is expected that there will be a positive relationship between coopetition dimensions and value creation in small firms.

\section{METHODOLOGY}

The survey research design was utilised in the study. The study area adopted for the study is Lagos State, Nigeria. Lagos State's choice was influenced by the fact that according to SMEDAN (2019), the state has the highest number of small firms in Nigeria and Lagos state is the seventh-largest economy in Sub Sahara Africa. The total population of small firms in this state are 8,042 . The raosoft sample-size calculator at $2 \%$ margin and a $95 \%$ confidence interval was employed in arriving at a sample size of 1398. According to Hamburg (1985), this sample size is sufficient and recommended for this survey and that it is most efficient to provide the right answers to the phenomenon at hand than a larger sample size where the survey responds to just a small percentage of the sample. A sample size $\geq$ of 400 reduces 
the error component so that small differences are regarded as statistically significant (Hair et al., 2010). Hence, considering the constraints of the research setting and theoretical aspect of this study, the sample size of 1398 was considered adequate for the study and making it possible for the generalisation of the result in line with the position of Mugenda and Mugenda (2003). Since the small firms in focus are diverse in characteristics, the sample size was further divided between the small firms in the service sector and manufacturing sector to ensure the respondents' adequate representation was taken from each category (service sector and manufacturing). This criterion was used to capture the small firms' sector adequately.

The questionnaire research instrument was utilised in the study. Mugenda and Mugenda (2003) posit that the questionnaire has a higher level of objectivity in comparison to other survey instruments. To ensure adequate representation of the sample size, the simple proportion method was employed. The questionnaires were equally divided between the top managers/operating officers in the selected service and manufacturing sector. Six hundred eighty-nine questionnaires were each distributed to the service and manufacturing sector. The questionnaire developed by Bengtsson and Johansson (2014) for coopetition and Markgraf (2020) for small firm value creation was adapted for the study with modification to capture the local dynamics. A seven Likert scale questionnaire was employed in the collection of data. According to Worimegbe (2020), the seven Likert scales provide a more accurate reflection and true evaluation of respondents' opinions. The Seven Likert scale measurement was designed from $1=$ least agreed, $7=$ strongly agreed. This also was to optimise the reliability and accuracy of the research instrument.

The research instrument consists of two sections tagged "Coopetition" and "Value Creation". The questionnaires were administered with the aid of research assistants to the small firms' owners/managers. A total of 1119 questionnaires $(80.04 \%)$ were retrieved (533 in the service industry, $77.3 \%$ and 586 in the manufacturing sector, $85.1 \%$ ). This shows that the sample size sufficiently satisfies the conditions for multivariate and subgroup analysis as established by Hair et al. (2010). The multivariate analysis was adopted in order to establish the interaction between the dimensions of coopetition (alliance portfolio management capabilities, entrepreneurial opportunities and industries specifics) and the dimensions of value creations (sales, new markets, new service or product added and value-added services). It will also allow the simultaneous assessment of all response variables in this study. This will help the researchers determine the most significant observed construct of coopetition explaining value creation in small firms. The analysis will also reveal the most significant observed measure of value creation, influenced by coopetition. Hence, the study utilises the partial least squares structural equation model (PLSSEM) to explain the interactions and strength of the path, evaluate how best the models fit the data and test each hypothesis. To test the overall significance of each of the hypothesis, the F-statistics was employed. It makes it possible for the estimation of the cause-effect relationship between the latent variables. The confirmatory factor analysis will enhance the testing of a priori model of the measured variables. The SMARTPLS 3 statistical tool is used in the analysis of data.

\subsection{Model Specification}

Anchored on the Games Theory, it is expected that coopetition will be a direct antecedent of value creation in small firms. Based on the above premise, the following models were formulated.

For Hypothesis 1:

$$
\text { Value Creation }=\beta_{0}+\beta_{1}(\mathrm{APM})+\mu,
$$

where $\mathrm{APM}=$ Alliance Portfolio Management, $\beta_{0}$ is the constant, $\beta_{1}$ is the coefficient estimator, $\mu$ is the error term.

For Hypothesis 2:

$$
\text { Value Creation }=\beta_{0}+\beta_{2}(\mathrm{EO})+\mu,
$$

where $\mathrm{EO}=$ Entrepreneurial Opportunities, $\beta_{0}$ is the constant, $\beta_{2}$ is the coefficient estimator, $\mu$ is the error term. 
Tab. 1: Operationalisation of Variables

\begin{tabular}{lll}
\hline Latent Variables & Observed Measurement & Studies \\
\hline Coopetition & Alliance Portfolio Management & Bengtsson and Johansson (2014) \\
& Entrepreneurial Opportunities & and authors modifications \\
& Industries Specifics & \\
\hline Value Creation & Sales & Markgraf (2020) \\
& New Markets & \\
& New Services Added & \\
& Value-Added Services & \\
\hline
\end{tabular}

For Hypothesis 3:

$$
\text { Value Creation }=\beta_{0}+\beta_{3} \text { (IS) }+\mu \text {, }
$$

where IS $=$ Industries Specifics, $\beta_{0}$ is the constant, $\beta_{3}$ is the coefficient estimator, $\mu$ is the error term.

Value Creation $=$ sales, new markets, new service or product added and value-added services.

From the above discussion, it is expected that all the dimensions of coopetition will exhibit a positive relationship with the dimensions of value creation. Hence there will be a directly proportionate relationship coopetition and value creation in the above model.

Tab. 1 reveals the coopetition and value creation measurements used in the study adopted from existing literature.

\subsection{Reliability and Validity}

The Confirmatory Factor Analysis (CFA) was employed in the psychometric properties' evaluation. The dimensions of the explanatory variable (coopetition) and the explained variable (value creation) were tested, and items in the model restricted to the conditions established by Fornell and Larcker (1981). In other words, the latent variables and internal consistency of the items were $>0.5$. The results obtained exhibit acceptable construct reliability and average variance. This is important in establishing content and construct validity. In ensuring face validity, the researchers' adopted the instruments utilised by previous while modifying them to reflect local dynamics. The questionnaires were administered twice at an interval of two weeks to the respondents in order to measure what it was intended to measure.

Tab. 2: Second-order Confirmatory Factor Analysis

\begin{tabular}{lcc}
\hline Measurement & $\begin{array}{c}\text { Construct } \\
\text { Reliability }\end{array}$ & $\begin{array}{c}\text { Average Variance } \\
\text { Extracted }\end{array}$ \\
\hline $\begin{array}{l}\text { Coopetition } \\
\text { Alliance Portfolio }\end{array}$ & 0.842 & 0.738 \\
Management & 0.808 & 0.713 \\
$\begin{array}{l}\text { Employment } \\
\text { Opportunities }\end{array}$ & 0.854 & 0.726 \\
Industry Specifics & 0.792 & 0.683 \\
Value Creation & 0.824 & 0.732 \\
Sales & 0.843 & 0.761 \\
New Markets & 0.789 & 0.686 \\
New Products & 0.886 & 0.715 \\
and Services & 0.782 & 0.653 \\
Value Added & Services &
\end{tabular}

Notes: Goodness-of-fit indices: CMIN $=2.82$

$\mathrm{CFI}=0.97 ; \mathrm{IFI}=0.96 ; \mathrm{RMSEA}=0.05$

The goodness-of-fit indices in Tab. 2 show that CMIN (chi-square/Degree of Freedom), Comparative Fit Index (CFI), Incremental Fit Indices (CFI) and Root Mean Square Error of Approximation (RMSEA) fall within the acceptable criteria established by Kline (2005). These indices are critical in testing each of the proposed models (hypothesis) in order to evaluate their confirmatory factor analysis and structural equation model. Hence, in establishing how best the explanatory variable and the dependent variable fit in this study, the goodness-of-fit indices would be employed in each hypothesis and their path analysis. According to Hair et al. (2010), the CMIN should be $<5$, RMSEA $<0.005$, CFI $\leq 0.90$ and $\mathrm{IFI} \leq 0.90$. 
Tab. 3: Sample Profile

\begin{tabular}{lc}
\hline Demographics & $\%$ \\
\hline Gender (1119) & \\
Male & 60.3 \\
Female & 39.7 \\
\hline Marital Status & \\
Singles & 28.7 \\
Married & 48.0 \\
Others (widowed and separated) & 23.3 \\
\hline Education & \\
Secondary & 19.3 \\
Tertiary & 80.3 \\
\hline Age of Respondents & \\
18-35 & 33.9 \\
$36-65$ & 52.4 \\
65 and above & 13.7 \\
\hline Years of Firm Existence & \\
1-5 & 46.2 \\
6-10 & 41.6 \\
Above 10 years & 12.2 \\
\hline
\end{tabular}

Tab. 3 shows the profile of the sample respondents. The profile reveals that the majority of the respondents are male $(n=675 ; 60.3 \%)$. This shows that most of the small enters are owned/managed by men. The majority of the sampled respondents are married $(n=537$; $48 \%$ ). An implication of this is that most of the small firms are owned/controlled by married people. In terms of the respondents' educational level, the survey reveals that many respondents attended tertiary institutions $(n=898$; $80.3 \%$ ). Most of the owners/managers have at least a minimum of polytechnic or university education. The majority of the respondents are between the working-class age in Nigeria, while the highest age bracket of firm owners/managers falls between 36-65 ( $n=586$; $52.4 \%$ ). The survey analysis shows that most small firms are between 1-5 years (of operations, while the small firms' average age $=5.56$ years. This indicates that most of the sampled firms are above the $1-5$ years liquidation period, as argued by Olaolu and Obaji (2020).

Tab. 4: Normality Analysis

\begin{tabular}{lccc}
\hline Tests & Model 1 & Model 2 & Model 3 \\
\hline Skewness & 0.464 & 0.682 & 0.598 \\
& $(0.000)$ & $(0.000)$ & $(0.000)$ \\
Kurtosis & 2.100 & 0.988 & 1.046 \\
& $(0.000)$ & $(0.000)$ & $(0.000)$ \\
$\begin{array}{l}\text { Cook Distance } \\
\begin{array}{l}\text { Independence } \\
\text { of Residual) }\end{array}\end{array}$ & 0.098 & 0.022 & 0.0744 \\
\hline
\end{tabular}

The normality test in Tab. 4 shows that the variables meet the requirements has recommended by Kline (2005). To ascertain for any undue influence on the model results, the Cook Distance was used, and the value shows that there is no presence of undue influence on the model. The kurtosis and skew measures are used to see whether the metrics met the normality generalisations (Kline, 2005). The descriptive statistics used to examine skew and kurtosis. According to Brown (2006), when using the structural equation model, acceptable skewness values range from -3 to +3 , and acceptable kurtosis values range from -10 to +10 . Hence the values of the measurements fall within the acceptable criteria for analysis in this study.

\section{RESULTS}

Fig. 1 shows the nature of coopetition among small firms in the service and manufacturing industry. $29 \%$ of small firms in the service industry are in coopetition to enhance alliance portfolio management while $33 \%$ of the small firms in the manufacturing industry are in for the same reason. The result also shows that $44 \%$ of small firms in the service industry and $41 \%$ of small firms in the manufacturing industry coopete for entrepreneurial opportunities enhancement while $27 \%$ of the small firms in the service industry and $26 \%$ of the small firms in the service industry conclude that industry specifics influences the nature of coopetition amongst them. The result established the nature of coopetition among small 


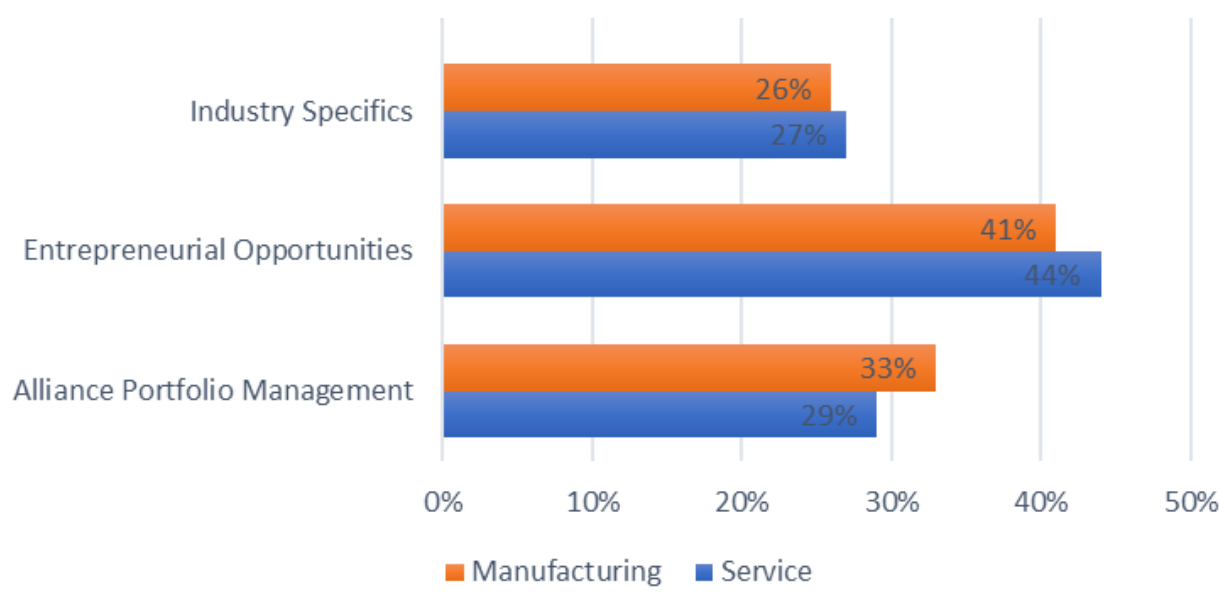

Fig. 1: Nature of Coopetition Among Small Firms in Nigeria

firms as being influenced by entrepreneurial opportunities. The result further reveals that the entrepreneurial opportunities drive for coopetition is more in the small firms' service industry than in the manufacturing industry.

\subsection{Hypotheses Testing}

Tab. 5: Hypothesis 1: The dimension of alliance portfolio management capabilities significantly affects value creation in small firms

\begin{tabular}{lccccc}
\hline Variable & B & SE & $\beta$ & T-value & Sig \\
\hline Alliance & & & & & \\
Portfolio & 0.832 & 0.017 & 0.845 & 49.71 & 0.000 \\
Management & & & & & \\
AdjR $^{2}$ & 0.74 & & & & \\
F-Stat & 63.022 & & & & \\
$p$ & 0.000 & & & & \\
\hline
\end{tabular}

The results in Tab. 5 show that coopetition significantly influences small firms value creation. There is a significant and positive relationship between coopetition and value creation $(\beta=0.845)$. The adjusted coefficient of variation $\left(R^{2}=0.714\right)$ shows that $71.4 \%$ variation in small firms value creation is caused by alliance portfolio management. The standard error $(\mathrm{SE}=0.017$ ) shows that the model is a good fit by indicating the extent alliance portfolio management accurately predicts value creation in small firms since the value falls between the accepted estimates 2.5. The unstandardised $(\mathrm{B}=0.832)$ reveals that value creation in small firms increase by 0.832 units when alliance portfolio management increases by a unit. The T-value $(t c=49.71 ; p=0.000)$ indicates that alliance portfolio management significantly predicts value creation in small firms. The F-stat $(F c=63.022 ; p=0.000)$ establishes that alliance portfolio management is reliable and significant in explaining value creation. The findings show that alliance portfolio management significantly drives value creation.

Fig. 2 reveals the estimates of the paths and the error variance of all the paths, estimating the influence of the alliance of portfolio management on coopetition. Hu and Bentler (1999) developed a combinational methodology for model fit evaluation using a $\mathrm{GFI}=0.90, \mathrm{CFI}=0.90$ and RMSEA $=0.05$. Reporting these estimators is critical in testing the hypotheses. They evaluate the current fit and the inconsistency between the data set and the measurement model relevant to the sample size. Root Mean Square Error of Approximation (RMSEA) indicates if the causality between variables can be analysed, and a value closer to 0 indicates a good fit. The Goodness fit Index (GFI) and the Comparative Fit Index compare the target data's compatibility with the null model's alignment. The goodness fit of the structural equation model shows CMIN $=2.132, p=0.000 ;$ GFI $=0.97$, RMSEA $=0.06$, IFI $=0.96, \mathrm{CFI}=0.95)$. The path coefficients show the interaction among 
the latent, observed and explained elements. The results show that AMP4 (coopetition increasing revenue, $t c=2.280)$ is the most explained variable in portfolio management affecting value creation. The path analysis also shows that new product and services $(t c=6.269)$ are the most significant value creation construct explained by alliance portfolio management. NPS3 (Our products and services are customised, $t c=5.830)$ is the most significant explaining new product and services.

Tab. 6: Hypothesis 2: The dimension of entrepreneurial opportunities significantly affects value creation in small firms

\begin{tabular}{lccccc}
\hline Variable & B & SE & $\beta$ & T-value & Sig \\
\hline Entrepreneurial & 0.896 & 0.033 & 0.893 & 27.06 & 0.000 \\
Opportunities & & & & & \\
AdjR $^{2}$ & 0.798 & & & & \\
F-Stat & 48.071 & & & & \\
$p$ & 0.000 & & & & \\
\hline
\end{tabular}

Tab. 6 result shows that entrepreneurial opportunities significantly influence small firms value creation. There is a significant and positive relationship between entrepreneurial orientation dimension and value creation $(\beta=0.893)$. The adjusted coefficient of variation $\left(R^{2}=0.798\right)$ shows that $79.8 \%$ variation in small firms value creation is caused by the quest for entrepreneurial opportunities among coopeting firms. The standard error $(\mathrm{SE}=0.033)$ shows that the model is a good fit by indicating the extent to which entrepreneurial opportunities predicts value creation in small firms since the value falls between the accepted estimates $\leq 2.5$. The unstandardised $(\mathrm{B}=0.896)$ reveals that value creation in small firms increase by 0.896 units when entrepreneurial opportunities increase by a unit. The T-value $(t c=27.06 ; p=0.000)$ indicates that entrepreneurial opportunities significantly predict value creation in small firms. The F-stat $(F c=48.071 ; p=0.000)$ establishes that entrepreneurial opportunities is reliable and significant in explaining value creation. The findings of the result assert that entrepreneurial opportunities significantly influence value creation.
Fig. 3 reveals the estimates of the paths and the error variance of all the paths, estimating the influence of entrepreneurial opportunities on value creation. The goodness fit of the structural equation model shows $\mathrm{CMIN}=1.532$, $p=0.000$, GFI $=0.96$, RMSEA $=0.05$, IFI $=0.97$, CFI $=0.98$ ). The path coefficients show the interaction among the latent, observed and explained elements. The results show that EO2 (Our alliance has brought about innovations in our operations, $t c=3.359$ ) is the most explained variable in entrepreneurial opportunities affecting value creation. The path analysis also shows that new product and services $(t c=6.332)$ are the most significant value creation construct explained by alliance portfolio management. NPS3 (Our products and services are customised, $t c=5.175)$ is the most significant explaining new product and services).

Tab. 7: Hypothesis 3: The dimension of industries specifics significantly affects value creation in small firms

\begin{tabular}{lccccc}
\hline Variable & B & SE & $\beta$ & T-value & Sig \\
\hline Industry & 0.825 & 0.041 & 0.811 & 19.780 & 0.000 \\
Specifics & & & & & \\
AdjR $^{2}$ & 0.657 & & & & \\
F-Stat & 44.231 & & & & \\
$p$ & 0.000 & & & & \\
\hline
\end{tabular}

The results in Tab. 7 show that industryspecifics has a significant influence on small firms value creation. There is a significant and positive relationship between industry specifics and value creation $(\beta=0.811)$. The adjusted variation coefficient $\left(R^{2}=0.657\right)$ shows that industry specifics cause $65.7 \%$ variation in small firms value creation. The standard error $(\mathrm{SE}=0.041)$ shows that the model is a good fit by indicating that industry-specifics accurately predict value creation in small firms since the value falls between the accepted estimates $\leq 2.5$. The unstandardised $(\mathrm{B}=0.825)$ reveals that value creation in small firms increases by 0.825 units when industry-specifics increases by a unit. The t-value $(t c=19.780 ; p=0.000)$ indicates that industry specifics significantly predict value creation in small firms. The F-stat $(F c=44.231, p=0.000)$ establishes that industry specifics are reliable and significant in 


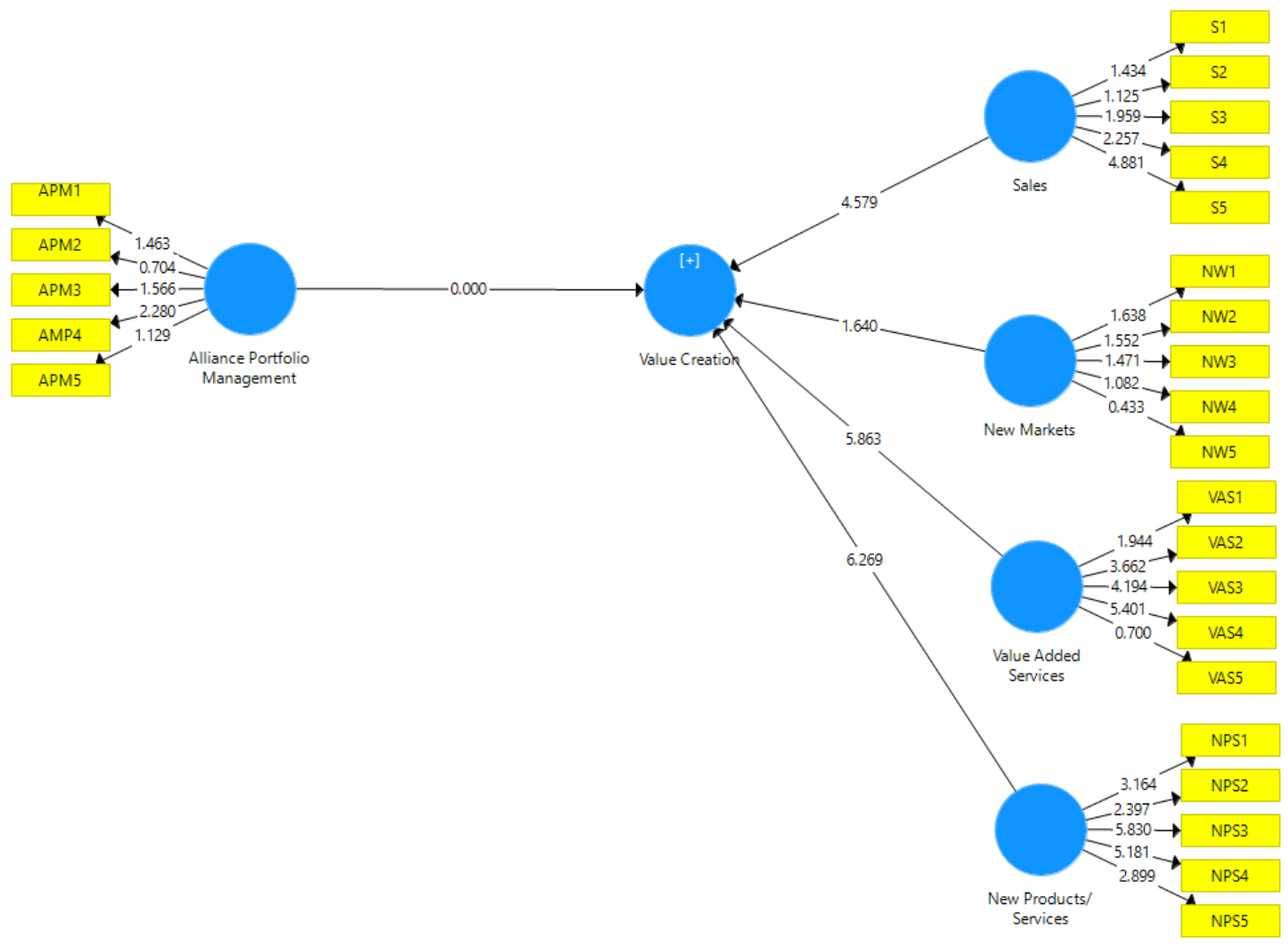

Fig. 2: Alliance of Portfolio Management on Coopetition

explaining value creation. The findings of the result assert that industry specifics drive value creation in small firms.

Fig. 4 reveals the estimates of the paths and the error variance of all the paths, estimating the effect of industry specifics on value creation. The goodness fit of the structural equation model shows CMIN $=1.677, p=0.000$, $\mathrm{GFI}=0.98, \quad \mathrm{RMSEA}=0.05, \mathrm{IFI}=0.96$, CFI $=0.97)$. The path coefficients show the interaction among the latent, observed and explained elements. The results show that IS3
(The need for customisation brought about collaborating with our rivals, $t c=3.502$ ) is the most explained variable in industry specifics influencing value creation. The path analysis also shows that new product and services $(t c=6.617)$ are the most significant value creation construct explained by industry specifics. NPS4 (Our products and services are unique to each type of customer, $t=5.858$ ) is the most significant explaining new product and services.

\section{DISCUSSIONS}

The survey analyses in figure 1 show the nature of coopetition prevalent in small firms. $29 \%$ of the service industry firms assert that they utilise the coopetition strategy to capture the difficult markets and manage their portfolio al- liance. In comparison, $33 \%$ of small firms in the manufacturing industry indicate that they are coopetition for alliance portfolios. This implies that many small firms coopete with different industry rivals to access more resources and 


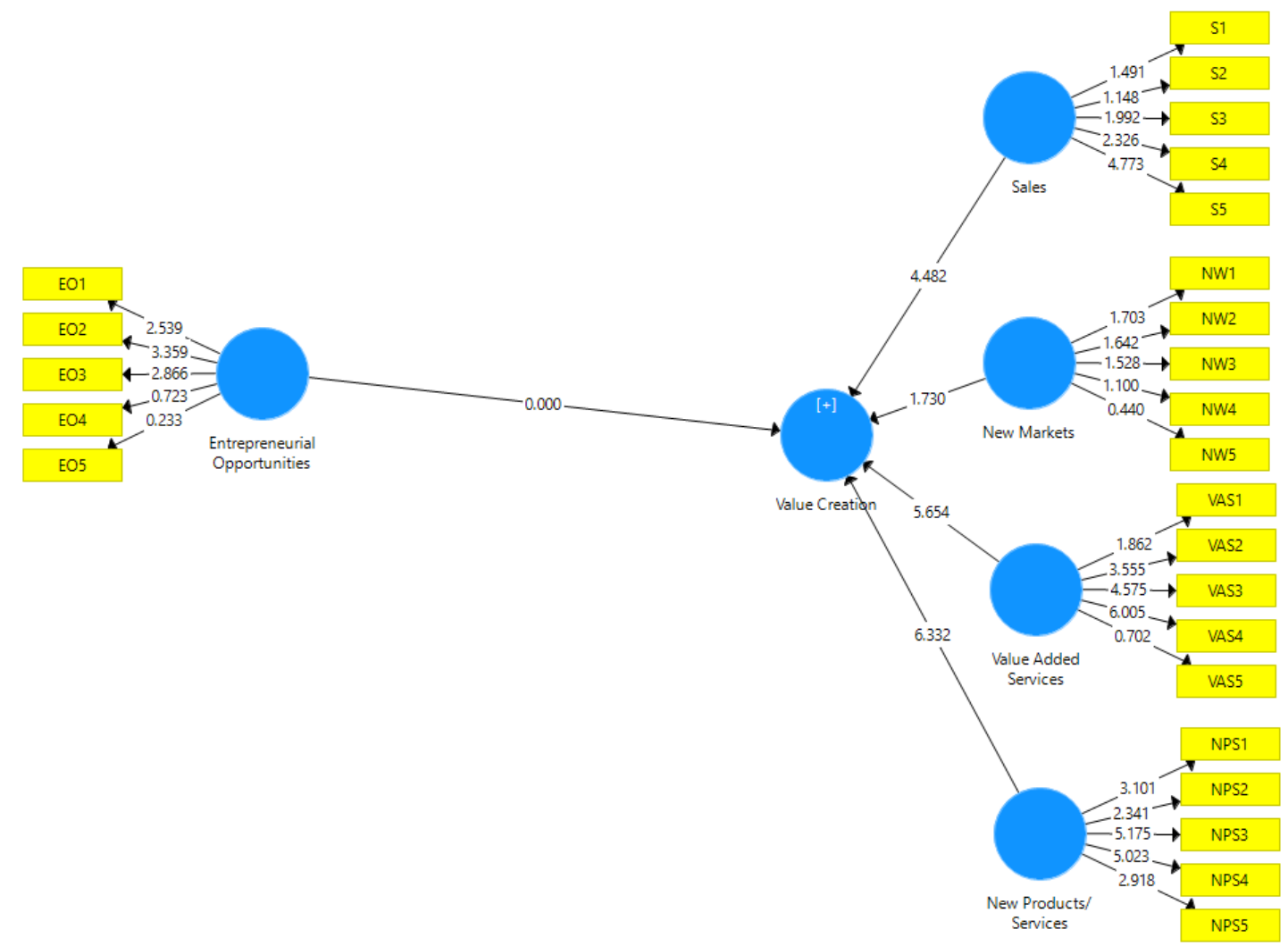

Fig. 3: Entrepreneurial Opportunities on Value Creation

information. However, in achieving the study's first objective, which determines the nature of coopetition among small firms in Nigeria, the findings reveal that most small firms are involved in coopetition because of entrepreneurial opportunities. Small firms explore and exploit coopetition as a strategy to create better services and products and achieve profitability. $44 \%$ of service firms and $41 \%$ of manufacturing small firms are involved in coopetition to access and utilise entrepreneurial opportunities. The result corroborates Bengtsson and Johansson (2014) and Worimegbe (2020) established that firms are involved in coopetition to take advantage of opportunities they would not have accessed as standalone firms.

Hypothesis one reveals the interactions between the dimensions of alliance portfolio management and value creation in small firms. The findings indicate that alliance portfolio management is a driver of value creation in small firms. The more firms are involved in alliance portfolio management, the more they can create values that will lead to better performance in the long run. The result also shows that the need to increase revenue in alliance portfolio management drives customisation in new products and services. It was also revealed that new product and services are the main essence of value creation in small firms. The findings support Czakon et al. (2020) and Dyer and Singh (1998) revealed that alliance portfolio management would enhance the firm's capacity and position in achieving competitiveness while increasing its networks and activities.

Hypothesis two indicates the degree of influence of entrepreneurial opportunities dimensions on value creation dimensions in small firms. The result shows that entrepreneurial opportunities significantly influence value creations. This implies that the need for the interfirm network is driven by the need to explore 


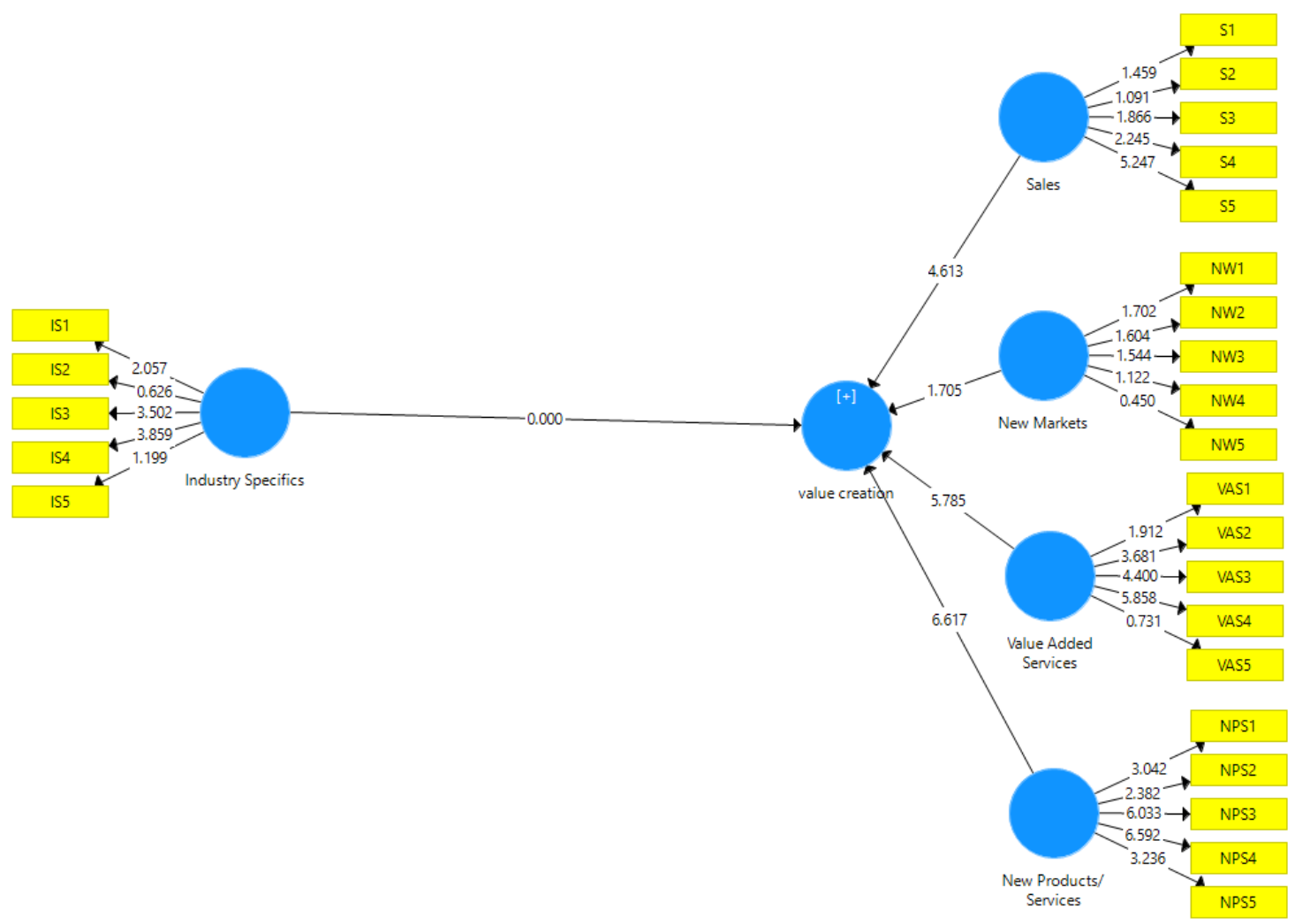

Fig. 4: Industry Specifics on Value Creation

and exploit entrepreneurial opportunities, and this leads to an increase in new product and services. The results show that alliance in coopetition has brought about innovations in small firms' operations, which has made it possible to create more opportunities leading to value creation. In terms of value creation, small firms need to exploit entrepreneurial opportunities to create new products and services to customise services and products. The result adds credence to the opinions of Klein (2010) and Ritala and Hurmelinna-Laukkanen (2009), who adds that entrepreneurial opportunities strategy is pivotal to creating value while supporting the arguments by Shane and Venkataraman (2000) that the strategies employed in pursuing opportunities could create more values for the firm.

The third hypothesis shows the degree of effect of industry specifics dimensions on small firms value creation. The result established that industry specifics significant affect value creation. The more industry-specific network increases, the more the small firms' capacity to create new product and services and stay profitable and competitive in the long run. The interaction of the individual dimensions reveals that the need for customisation by small firms has brought about coopetition, which greatly influences the uniqueness of product and services delivered to the different categories of customers. Bengtsson and Johansson (2014) and Machado (2016) suggest that participating in strategic alliances by small firms create values and compete with other firms in the market is strengthened by this finding.

The analysis also established coopetition and value creation dimensions a small should pursue par time. While the industry survey reveals that the entrepreneurial opportunities dimension is the most pursued by the service and manufacturing firms in the market, the inferential statistics reveal that alliance portfolio management is the most significant coopetition dimension $(t=49.71)$ which small firms should 
pursue. The result also shows that new product and services are the most significant value creation measure in small firms. Hence, small firms should first explore and exploit ways to provide new products and services that meet the customers' needs. In comparison, this contradicts Jorgenson's (2015) opinion which suggests firms should consider revenue and cost of providing services first that value creation should be measured in terms of revenue and competitive cost of providing a service. This study's findings address key issues and provide direction for small firms in attaining competi- tiveness through the process of value creation. Small firms should be involved in coopetition strategy. Firms which operate simultaneous and direct relationships or networks will enjoy increased capacity and capture more markets. While coopetition is not the only strategy to capture new markets, this study provides a more robust strategy that makes the small firms collaborate with their rivals to capture access to a diversity of resources and information. Small firms also provide new product and services that will enable them to capture the market and compete favourably with the larger firms.

\section{CONCLUSION}

The study examined the influence of coopetition on small firm value creation. Extant literature provided the need to examine the nature of coopetition among small firms and determine the extent to which coopetition affects small firms' value creation and the dimension of coopetition and value creation small firms should pursue at a particular period of time. Utilising the dimensions of alliance portfolio management, entrepreneurial opportunities, and industry specifics for coopetition, the study established that coopetition dimensions significantly affect small firms' value creation (valueadded services, new markets, new products and services, and sales. The study also reveals that alliance portfolio management is the most significant dimension of coopetition that small firms should first pursue, while the creation of new products and services should be the first form of value creation to be created by small firms. The study's path analysis shows that in the process of value creation, firms should not consider exploring new markets as these do not have any significant effect. Coopetition should be to achieve new products; value-added services and increase revenue through sales.

The study recommends that small firms integrate coopetition into their strategy to remain relevant, increase their revenue, customise their services through value-added services, and create new products and services. Small firms should be moved by the need to pursue alliance portfolio management before entrepreneurial opportunities and industry specifics. It is also pivotal for small firms to customise their product and services in sustaining their value in the market place.

\section{REFERENCES}

Ackerman, S. J. 1999. Are Small Firms Important? Their Role and Impact. Springer. DOI: 10.1007/978-1-4615-5173-7.

Aladejebi, O. 2020. Managing Small Firms in Nigeria During Covid-19 Crisis: Impact and Survival Strategies. IOSR Journal of Business and Management, 22 (8), 24-34. DOI: $10.9790 / 487 \mathrm{X}-2208012434$.
Arndt, M., Grewe, I. and Unger, A. 2018. Co-Opetition in the Banking Industry: Overcoming the Rift Between Financial Institutions and FinTechs [online]. BearingPoint. Available at: https://www. bearingpoint. com/files/WP_1084_EN_Coopetition_Banking_ Industry . pdf ?download=0anditemId $=284371$ [Accessed 2020, November 14]. 
Bengtsson, M. and Johansson, M. 2014. Managing Coopetition to Create Opportunities for Small Firms. International Small Business Journal: Researching Entrepreneurship, 32 (4), 401-427. DOI: $10.1177 / 0266242612461288$.

Bengtsson, M. and Kock, S. 2000. Coopetition in Business Networks - to Cooperate and Compete Simultaneously. Industrial Marketing Management, 29 (5), 411-426. DOI: 10.1016/S0019-8501(99)00067-X.

Bengtsson, M., Raza-Ullah, T. and Vanyushyn, V. 2016. The Coopetition Paradox and Tension: The Moderating Role of Coopetition Capability. Industrial Marketing Management, 53, 19-30. DOI: 10.1016/j.indmarman.2015.11.008.

Bhuiyan, B. A. 2016. An Overview of Game Theory and Some Applications. Philosophy and Progress, 59 (1-2), 112-118. DOI: 10.3329/pp.v59i1-2.36683.

Bicchieri, C. 2007. Game Theory: Some Personal Reflections. In Hendricks, V. F. and Hansen, P. G. (eds.). Game Theory: 5 Questions. Copenhagen: Automatic Press.

Bicchieri, C. and Sillari, G. 2005. Game Theory and Decision Theory. In Borchert, D. (ed.). The Encyclopedia of Philosophy. 2nd ed. Detroit: Macmillan.

Bouncken, R. B. and Fredrich, V. 2016. Business Model Innovation in Alliances: Successful Configurations. Journal of Business Research, 69 (9), 3584-3590. DOI: $10.1016 /$ j.jbusres.2016.01.004.

Bouncken, R. B., Gast, J., Kraus, S. and Bogers, M. 2015. Coopetition: A Systematic Review, Synthesis, and Future Research Directions. Review of Managerial Science, 9 (3), 577-601. DOI: $10.1007 / \mathrm{s} 11846-015-0168-6$.

Bouncken, R. B. and Kraus, S. 2013. Innovation in Knowledge-Intensive Industries: The Double-Edged Sword of Coopetition. Journal of Business Research, 66 (10), 2060-2070. DOI: $10.1016 /$ j.jbusres.2013.02.032.

Brown, T. A. 2006. Confirmatory Factor Analysis for Applied Research. New York: Guilford Press.

CRICK, J. M. and CRICK, D. 2019. Developing and Validating a Multi-Dimensional Measure of Coopetition. Journal of Business 8 Industrial Marketing, 34 (4), 665-689. DOI: 10.1108/JBIM-07-2018-0217.

Crick, J. M. and CRICK, D. 2020. Coopetition and COVID-19: Collaborative Business-to-Business Marketing Strategies in a Pandemic Crisis. Industrial Marketing Management, 88, 206-213. DOI: 10.1016/j.indmarman.2020.05.016.

Cygler, J., Sroka, W., Solesvik, M. and DęBKowska, K. 2018. Benefits and Drawbacks of Coopetition: The Roles of Scope and Durability in Coopetitive Relationships. Sustainability, 10 (8), 2688. DOI: $10.3390 /$ su10082688.
Czakon, W. 2018. Network Coopetition. In Fernandez, A.-S., Chiambaretto, P., Le Roy, F. and Czakon, W. (eds.). The Routledge Companion to Coopetition Strategies. DOI: $10.4324 / 9781315185644-5$.

Czakon, W. and Czernek, K. 2016. The Role of TrustBuilding Mechanisms in Entering into Network Coopetition: The Case of Tourism Networks in Poland. Industrial Marketing Management, 57 (2), 64-74. DOI: 10.1016/j.indmarman.2016.05.010.

Czakon, W., Klimas, P. and Mariani, M. 2020. Behavioral Antecedents of Coopetition: A Synthesis and Measurement Scale. Long Range Planning, 53 (1), 79-123. DOI: 10.1016/j.lrp.2019.03.001.

Czakon, W. and Rogalski, M. 2014. Coopetition Typology Revisited - a Behavioural Approach. International Journal of Business Environment, 6 (1), 28-46. DOI: 10.1504/IJBE.2014.058022.

DAvidow, M. 2018. Value Creation and Efficiency: Incompatible or Inseparable? Journal of Creating Value, 4 (1), 123-131. DOI: $10.1177 / 2394964318768904$.

Di Benedetto, C. A., Lindgreen, A., Storgand, M. and Clarke, A. H. 2019. How to Collaborate Really Well with Practitioners. Industrial Marketing Management, 82 (3), 1-8. DOI: $10.1016 /$ j.indmarman.2019.08.001.

Dyer, J. H. and Singh, H. 1998. The Relational View: Cooperative Strategy and Sources of Interorganizational Competitive Advantage. Academy of Management Review, 23 (4), 660-679. DOI: $10.2307 / 259056$.

Fornell, C. and LARCKer, D. F. 1981. Evaluating Structural Equation Models with Unobservable Variables and Measurement Error. Journal of Marketing Research, 18 (1), 39-50. DOI: $10.2307 / 3151312$.

Gardete, P. M. 2016. Competing Under Asymmetric Information: The Case of Dynamic Random Access Memory Manufacturing. Management Science, 62 (11), 3291-3309. DOI: 10.1287/mnsc.2015.2297.

Geckil, I. K. and Anderson, P. L. 2010. Applied Game Theory and Strategic Behavior. 1st ed. London: CRC Press.

Georgescu-Roegen, N. 1971. The Entropy Law and the Economic Process. Harvard University Press.

Gnyawali, D. R. and Charleton, T. R. 2018. Nuances in the Interplay of Competition and Cooperation: Towards a Theory of Coopetition. Journal of Management, 44 (7), 2511-2534. DOI: $10.1177 / 0149206318788945$.

Hair, J. F., Black, W. C., Babin, B. J. and Anderson, R. E. 2010. Multivariate Data Analysis: A Global Perspective. 7th ed. Upper Saddle River: Pearson. 
Hamburg, M. 1985. Basic Statistics: A Modern Approach. Dryden Press.

HAyes, A. 2020. Coopetition. Investopedia [online]. Available at: https://www . investopedia.com/terms/c/coopetition.asp. [Accessed 2020, September 1].

Hoffmann, W. H. 2007. Strategies for Managing a Portfolio of Alliances. Strategic Management Journal, 28 (8), 827-856. DOI: 10.1002/smj.607.

Hu, L.-T. and Bentler, P. M. 1999. Cutoff Criteria for Fit Indexes in Covariance Structure Analysis: Conventional Criteria Versus New Alternatives. Structural Equation Modeling, 6 (1), 1-55. DOI: $10.1080 / 10705519909540118$.

JANkowskA, B. 2010. Coopetition and Internationalisation of a Company - the Case of Firms in the Wielkopolska Voivodeship. Journal of International Studies, 3 (1), 94-102. DOI: $10.14254 / 2071-8330.2010 / 3-1 / 10$.

Jorgenson, E. 2015. Why Value Creation is the Foundation of Business: How to Define It, Measure It, and Manage It. Evergreen [online]. Available at: https: //medium.com/evergreen-business-weekly/ why-value-creation-is-the-foundation-of -business-how-to-define-it-measure-it - and-manage-it-147c92b87aca.

KLein, P. G. 2010. Opportunity and the Entrepreneur. Mises Institute [online]. Available at: https://mises.org/ library/opportunity-and-entrepreneur. [Accessed 2020, September 1].

KLine, R. B. 2005. Principles and Practice of Structural Equation Modeling. 2nd ed. Methodology in the Social Sciences. Guilford Press.

Kylänen, M. and Rusko, R. 2011. Unintentional Coopetition in the Service Industries: The Case of Pyhä-Luosto Tourism Destination in the Finnish Lapland. European Management Journal, 29 (3), 193-205. DOI: 10.1016/j.emj.2010.10.006.

Le Roy, F. and Czakon, W. 2016. Managing Coopetition: The Missing Link Between Strategy and Performance. Industrial Marketing Management, 53 (1), 3-6. DOI: $10.1016 /$ j.indmarman.2015.11.005.

Lieberman, M. B. and Balasubramanian, N. 2007. Measuring Value Creation and Its Distribution among Stakeholders of the Firm [online]. Available at: https : //ssrn. com/abstract $=2382099$. DOI: $10.2139 /$ ssrn.2382099.

Luo, Y. 2007. A Coopetition Perspective of Global Competition. Journal of World Business, 42 (2), 129-144. DOI: 10.1016/j.jwb.2006.08.007.

Machado, H. P. V. 2016. Growth of Small Firms: A Literature Review and Perspectives of Studies. Gestão \& Produção, 23 (2), 419-432. DOI: 10.1590/0104-530X1759-14.
MARKGRAF, B. 2020. Introduction to Value Creation in Business. Chron [online]. Available at: https://smallbusiness.chron.com/ introduction-value-creation-business-42606. html. [Accessed 2020, November 16].

McKelvie, A. and Wiklund, J. 2010. Advancing Firm Growth Research: A Focus on Growth Mode Instead of Growth Rate. Entrepreneurship: Theory and Practice, 34 (2), 261-288. DOI: 10.1111/j.1540-6520.2010.00375.x.

Merchant, K. A. and Sandino, T. 2009. Four Options for Measuring Value Creation. Journal of Accountancy, 208 (2), 34-37.

Moore, J. F. 1993. Predators and Prey: A New Ecology of Competition. Harvard Business Review, 71 (3), 75-86.

Morris, M. H., KoçAK, A. and Özer, A. 2007. Coopetition as a Small Business Strategy: Implications for Performance. Journal of Small Business Strategy, 18 (1), 35-56. DOI:

Mugenda, O. M. and Mugenda, A. G. 2003. Research Methods: Quantitative and Qualitative Approaches. Nairobi: African Centre for Technology Studies.

Olaolu, D. and OBaji, N. O. 2020. An Assessment on the Influence of Entrepreneurial Training, RiskTaking and Innovativeness on SMEs Development in Nigeria. Journal of Economics and Business, 3 (1), 254-269. DOI: 10.31014/aior.1992.03.01.195.

Ornstein, M. and SAndahl, M. 2015. Coopetition and Business Models: How Can They Be Integrated, and What Effect Does It Have on Value Creation, Delivery and Capture? Unpublished Thesis. Umeå School of Business and Economics.

Park, B.-J., Srivastava, M. K. and Gnyawali, D. R. 2014. Impact of Coopetition in the Alliance Portfolio and Coopetition Experience on Firm Innovation. Technology Analysis and Strategic Management, 26 (8), 893-907. DOI: $10.1080 / 09537325.2014 .913016$.

Randolph, R. V., Hu, H. and Silvernail, K. 2018. Knowledge Networking and Coopetition: The Role of Shared Technology in Promoting Goal Convergence. 2018 Western Academy of Management Conference, 59, 9.

Ritala, P. and Hurmelinna-Laukkanen, P. 2009. What's in It for Me? Creating and Appropriating Value in Innovation-Related Coopetition. Technovation, 29 (12), 819-828. DOI: 10.1016/j.technovation.2009.07.002.

Ritala, P., Kraus, S. and Bouncken, R. B. 2016. Introduction to Coopetition and Innovation: Contemporary Topics and Future Research Opportunities. International Journal of Technology Management, 71 (1/2), 1-9. DOI: 10.1504/IJTM.2016.077985. 
Ritala, P. and Sainio, L.-M. 2014. Coopetition for Radical Innovation: Technology, Market and Business-Model Perspectives. Technology Analysis and Strategic Management, 26 (2), 56-69. DOI: $10.1080 / 09537325.2013 .850476$.

Ritala, P. and Tidström, A. 2014. Untangling the Value-Creation and Value-Appropriation Elements of Coopetition Strategy: A Longitudinal Analysis on the Firm and Relational. Scandinavian Journal of Management, 30 (4), 498-515. DOI: 10.1016/j.scaman.2014.05.002.

Saebi, T. 2011. Succesfully Managing Alliance Portfolios: An Alliance Capability View. Universitaire Pers Maastricht.

Samuelson, P. A. and Nordhaus, W. D. 2010. Economics. New York: McGraw-Hill.

Seetharaman, M. and Gallucci, J. 2020. How Global 500 companies are Utilising Their Resources and Expertise During the Coronavirus Pandemic. Fortune [online]. Available at: https://fortune.com/2020/04/13/ global500-companies-coronavirus-response - covid-19-pandemic/.

[Accessed 2020, November 21].

Shane, S. and Venkataraman, S. 2000. The Promise of Entrepreneurship as a Field of Research. Academy of Management Review, 25 (1), 217-226. DOI: $10.5465 / \mathrm{amr} .2000 .2791611$.

Sharma, P. and Carney, M. 2012. Value Creation and Performance in Private Family Firms: Measurement and Methodological Issues. Family Business Review, 25 (3), 72-89. DOI: $10.1177 / 0894486512457295$.

SMEDAN. 2019. National Survey Of Micro Small \& Medium Enterprises (MSMEs) [online]. Available at: https://smedan.gov.ng/images/NATIONAL\% 20SURVEY $\% 200 F \% 20$ MICRO $\% 20$ SMALL $\% 20 \& \% 20$ MEDIUM $\%$ 20ENTERPRISES $\% 20$ (MSMES) , $\% 20 \% 202017 \% 201$. pdf.

Soppe, C., Lechner, B. and Dowling, M. 2014. Vertical Coopetition in Entrepreneurial Firms: Theory and Practice. Journal of Small Business and Enterprise Development, 21 (4), 548-564. DOI: 10.1108/JSBED-03-2014-0052.
Stadtler, L. and Van Wassenhove, L. N. 2016. Coopetition as a Paradox: Integrative Approaches in a Multi-Company, Cross-Sector Partnership. Organisation Studies, 37 (5), 655-685. DOI: $10.1177 / 0170840615622066$.

Thiel, P. and Masters, B. 2018. Zero to One: Notes on Startups, or How to Build the Future. Amazon, United Kingdom.

Thomason, S. J., Simendinger, E. and Kierman, D. 2013. Several Determinants of Successful Coopetition in Small Business. Journal of Small Business and Entrepreneurship, 26 (1), 15-28. DOI: $10.1080 / 08276331.2012 .761800$.

Turner, J. and Akinremi, T. 2020. The Business Effects of Pandemics: A Rapid Literature Review [online]. Enterprise Research Centre. Available at: https://www .enterpriseresearch. ac.uk/wp-content/uploads/2020/04/ ERC-Insight-The-business-effects-of-pandemics -\% E2\%80\%93-a-rapid-literature-review-Final. pdf. [Accesssed 2020, October 10].

Walley, K. 2007. Coopetition: An Introduction to the Subject and an Agenda for Research. International Studies of Management and Organization, 37 (2), 11-31. DOI: 10.2753/IMO0020-8825370201.

Wang, Y. and Krakover, S. 2008. Destination Marketing: Competition, Cooperation or Coopetition? International Journal of Contemporary Hospitality Management, 20 (2), 126-141. DOI: 10.1108/09596110810852122.

Windsor, D. 2013. Corporate Social Responsibility and Irresponsibility: A Positive Theory Approach. Journal of Business Research, 66 (10), 1937-1944. DOI: $10.1016 /$ j.jbusres.2013.02.016.

Worimegbe, P. M. 2020. Coopetition and Customers' Experience in the Nigerian Banking Sector: The Moderating Effect of Technology. Global Journal of Business, Economics and Management: Current Issues, 10 (2), 111-123. DOI: $10.18844 /$ gjbem.v10i2.4847.

ZGARni, B. 2019. Cooperation or Coopetition Strategy: What is the Best Strategy Face to Competition' Intensity and Strategic Capabilities? International Review of Management and Marketing, 9 (5), 114-124. DOI: 10.32479 /irmm.8408.

\section{AUTHOR'S ADDRESS}

Adedeji Saidi Adelekan, Department of Business Administration, Dominican University, Oyo State, Nigeria, e-mail: elevatedej@gmail.com

James Olanipekun Ojo, Department of Business Administration, Mountain Top University, Ogun State, Nigeria

Powel Maxwell Worimegbe, Department of Business Administration, Olabisi Onabanjo

University, Ago-Iwoye, Ogun State, Nigeria, e-mail: powelmaxwell@yahoo.com 